\title{
Family Bonds that Support Coping with Chronic Childhood Illness in the State of Paraíba, Brazil
}

Maria Elizabete de Amorim Silva', Isabelle Pimentel Gomes², Vanessa Medeiros da Nóbrega ${ }^{3}$, Amanda Narciso Machado ${ }^{4}$, Elenice Maria Cecchetti Vaz ${ }^{3}$, Neusa Collet ${ }^{5}$

\section{Abstract}

Objective: Identify family bonds that support coping with chronic childhood illness in the state of Paraíba, Brazil, from the perspective of comprehensive care.

Method: Qualitative, descriptive-exploratory study was performed in a public hospital in the Brazilian state of Paraíba between December 2011 and March 2012 through semi-structured interviews with mothers of chronically ill children. Thematic analysis was used for the interpretation of the data.

Results: In this study it was identified that the supporting linkages constituted by the family were: the nuclear and extended family; friends; neighbours; the government; healthcare professionals; and mothers who share the same experience. The social support provided falls under different dimensions, such as instrumental support, emotional support, informational support, reinforcement, and positive social interaction.

Conclusion: Knowing the bonds that support families coping with chronic illness and their demands for attention and support is fundamental for providing comprehensive and humanised healthcare to those involved in this trajectory.

\section{Introduction}

The current epidemiological data of Brazil reveal a considerable increase in chronic disease [1]. The National Household Survey (Pesquisa Nacional por Amostra em Domicílio - PNAD), conducted by
1 Nurse, Master's degree candidate, Graduate Program in Nursing, Federal University of Paraíba (Universidade Federal da Paraíba, UFPB), João Pessoa, Paraíba, Brazil.

2 Nurse, Doctoral degree, Graduate Program in Nursing, UFPB, João Pessoa, Paraíba, Brazil.

3 Nurse, Doctoral degree candidate, Graduate Program in Nursing, UFPB, João Pessoa, Paraíba, Brazil.

4 Nurse, Master's degree candidate, Graduate Program in Nursing, UFPB, João Pessoa, Paraíba, Brazil.

5 Nurse, Doctoral degree, Professor, Graduate Program in Nursing, UFPB, João Pessoa, Paraíba, Brazil.

Contact information:

Maria Elizabete de Amorim Silva.

ఏ elizabeteamorim.enf@gmail.com

Keywords

Paediatric Nursing; Family

Relations; Social Support;

Chronic Disease. 
the Brazilian Institute of Geography and Statistics (Instituto Brasileiro de Geografia e Estatística - IBGE) and published in 2010, investigated 12 chronic conditions and revealed that $9.1 \%$ of children aged 0 to 5 years, $9.7 \%$ of children aged 6 to 13 years, and $11 \%$ of adolescents aged 14 to 19 years had chronic disease [2].

The diagnosis of a chronic disease imposes changes in everyday life because it triggers organic, emotional, and social changes that require a permanent adaptation on the part of children and their families [3-5]. The mother, the main carer, experiences moments associated with the routine care of the disease that can result in health impairment, such as emotional distress and difficulty to adapt to a new routine $[3,6]$, requiring special attention while she is the main care provider [3,5]. However, it is understood that the carer, either the mother or another person in charge, needs to have balanced emotional, physical, and psychological health to therefore contribute to the child's recovery and well-being.

Thus, the healthcare team needs to intervene to provide support, monitoring, and guidance to accommodate carers and their demands [7] to strengthen them so that they can overcome the adversities of the chronic childhood condition.

The comprehensive care of the chronically ill child is achieved when it goes beyond the biological and treatment aspects and also aims to build a unique and humanised assistance that includes assistance to the family that considers all aspects associated with life and the bonds established with the environment in which they live $[5,8]$.

The support bonds of the family, understood as a relationship in the personal dimension, are composed of members of the social network who provide support to the family and contribute to the development of coping strategies [5, 9], which generate positive responses in the experience with the condition [10, 11].

The social support offered by the support bonds involves the different ways in which the network members can assist the family in properly coping with the child's condition [5, 12]. Different types of support can be provided: emotional support, which comprises affection, esteem, respect, and consideration; reinforcement support, which is associated with positive statements received by the family about the care provided and the results obtained; informational support, which involves offering suggestions, information, advice, and opinions; instrumental support, which comprises financial assistance, material resources, and services offered to the family by individuals, institutions, and other means $[9,13]$; and positive social interaction, understood as the availability of individuals with whom it is possible to have fun and relax [14].

Based on these dimensions, an important part of the role of healthcare professionals is knowing the families and their interactions with their social support network to strengthen and maintain the support bonds. Accordingly, research has demonstrated that positive adjustment is influenced by the level of family support offered to the chronically ill child and his or her parents [6].

From that perspective, health professionals, upon discovering the context of life, values, familiar dynamics and necessities of caring for the families of those children, can contribute to the construction of new supporting linkages. As such, they strengthen support networks of these individuals and collaborate with the process of confronting chronic disease [15].

In Public Health, knowing the social support network of these families can positively influence the determinants of health because these organised efforts are targeted towards maintaining or improving health levels to protect, promote, and restore health [16]. Nevertheless, primary healthcare teams from both Primary Healthcare and hospitals need to rethink their practices to stimulate the formation of bonds that can provide effective support and therefore offer comprehensive care to families of chronically ill children [3]. 
Despite the importance of the support bonds for the children and their families who experience the chronic condition, studies $[5,17,18]$ have shown that these bonds are not always effective. They can be limited, disconnected, fragile, and unable to offer continuous support that is suitable for the family's demands throughout the course of the disease.

Accordingly, this study is guided by the following question: What are the supporting linkages of Brazilian families in confronting chronic disease in infancy, with respect to the perspective of integral care? To answer this question, the objective of this study is to identify family bonds that support coping with chronic childhood illness in the state of Paraíba, Brazil, from the perspective of comprehensive care.

\section{Method}

Qualitative, exploratory-descriptive study done at a Paediatric Unit of a federal public hospital located in the state of Paraíba, Brazil. It addressed the family, and the individual responses of mothers were used to understand the context experienced by the family regarding the support bonds for coping with chronic childhood illness.

Data were collected with seven mothers of children with diagnoses of chronic disease who were hospitalized between December 2011 and March 2012 through semi-structured interviews [19], which were conducted using the following guiding questions: After your child's disease was discovered, did you receive any type of support to help care for him/ her? Who supported you in the care of your child? How was the support received?

The inclusion criteria were as follows: individuals accompanying a chronically ill child in the hospital under study; who had no communication problems; aged 18 years old or over; and having a child with a confirmed diagnosis of chronic illness for more than six months, without time limit, because after that period of time, the family has experienced different stages of the disease and have parameters to identify the family bonds that offer support in this process.

All mothers of chronically ill children hospitalised during the data collection period who met the inclusion criteria participated in the study. The data stopped being collected when the sufficiency criterion was met, that is, when an assessment of the collected empirical material made it possible to construct a comprehensive picture of the object of study [20].

The empirical data was interpreted by means of thematic analysis, following three stages: pre-analysis, in which the transcripted interviews were organized in a determined order, starting a classification; exploration of the material, with an exhaustive review of texts, making a critical analysis with them to develop a relevant structure of analysis for the project; and interpretation of results, corresponding to the final analysis with the regrouping of similar topics and the construction of empirical categories [19]. Finally, the following empirical categories were constructed: bonds with the nuclear family; bonds with the extended family; friends and neighbours as sources of family support; and social support relations in healthcare services.

The study was conducted in accordance with Resolution No. 466/12 of the National Health Council of Brazil and was approved by the Research Ethics Committee of the institution in which it was conducted (Protocol \#083/2011, CAAE \#50019715.6.0000.5183). All subjects signed a free and informed consent form. To ensure the anonymity of the participants in the presentation of the results, the word "Mother" is used, followed by an ordinal number indicating the order in which the participant was interviewed.

\section{Results}

Seven mothers whose children had the following diagnoses participated in the study: Mother 1: congenital dystrophic epidermolysis bullosa; Mother 2: Down syndrome, Cushing's syndrome, and treatment-resistant severe persistent asthma; 
Table 1. Characterization of participants in the study of residents of the state of Paraíba, Brazil.

\begin{tabular}{|c|c|c|c|}
\hline $\begin{array}{l}\text { Parental } \\
\text { relationship with } \\
\text { child }\end{array}$ & Diagnosis of child & $\begin{array}{l}\text { Time period } \\
\text { of diagnosis }\end{array}$ & $\begin{array}{l}\text { Approximate monthly } \\
\text { wage of family }\end{array}$ \\
\hline Mother 1 & Congenital dystrophic epidermolysis bullosa & 5 years & $R \$ 1.300,00(\$ 364,15)$ \\
\hline Mother 2 & $\begin{array}{l}\text { Down syndrome, Cushing's syndrome, and } \\
\text { treatment-resistant severe persistent asthma }\end{array}$ & $\begin{array}{l}2 \text { years and } \\
10 \text { months }\end{array}$ & $R \$ 540,00(\$ 151,26)$ \\
\hline Mother 3 & Idiopathic thrombocytopenic purpura & 4 years & $R \$ 1.080,00(\$ 302,52)$ \\
\hline Mother 4 & Nephrotic syndrome & 3 years and 6 months & $R \$ 540,00(\$ 151,26)$ \\
\hline Mother 5 & Leukaemia & 5 years & $\mathrm{R} \$ 540,00(\$ 151,26)$ \\
\hline Mother 6 & Chronic neuropathy & 6 months & $\mathrm{R} \$ 5.000,00(\$ 1.400,56)$ \\
\hline Mother 7 & Nephrotic syndrome & 5 years & $R \$ 540,00(\$ 151,26)$ \\
\hline
\end{tabular}

Mother 3: idiopathic thrombocytopenic purpura; Mother 4: nephrotic syndrome; Mother 5: leukaemia; Mother 6: chronic neuropathy; and Mother 7: nephrotic syndrome. The time of diagnosis varied between six months and five years. All families were from the state of Paraíba. Four families earned the minimum monthly wage, and three had sickness benefits as the only source of steady income. The other families had an income ranging from two to eight times the minimum monthly wage, keeping in mind that the minimum salary at the time was $\mathrm{R} \$ 540(\$ 151,26)$. The data is clarified in table one to be visualized better. (Table 1)

\section{Bonds with the nuclear family}

Support bonds arise in the nuclear family, whose members live in the same household, during the reorganisation of the family dynamics for coping with the chronic childhood illness. Healthy siblings help with household chores and care of the child, contributing to hygiene care and medication schedules. This support is considered essential by the mother, who reveals the presence of trust in this relationship.

My daughter is the one who helps, takes care of the house, washes clothes, [...] I prepare the food and wash his [the child's] clothes.

Mother 1
My 12-year-old boy bathes, organises. [...] He is my right hand. [...] He helps give the medicine. He says: "The boy's medicine, it's time!". [...] I take care of the house while he takes care of the child. [...] This is a great help.

Mother 2.

Another support bond present in the nuclear family is paternal support, which is offered to the mother to minimise the burden of caregiving and responsibility. The instrumental support provided by this family member is associated with financial support, with the father being responsible for acquiring the items necessary for the continuation of life.

The money that he [father] earns is used for the house. [...] He buys things [food, hygiene and cleaning items, medicine], he does not mind.

Mother 2.

The father also provides other forms of support, such as taking care of the healthy child who lives in the household, while the mother accompanies the sick child during hospitalisation.

The boy [another child] is there [at home] with his father.

Mother 3. 


\section{Bonds with the extended family}

Grandparents can offer financial support by providing food and other items needed for family subsistence. In addition, they help care for the healthy siblings and the chronically ill child, reducing the concerns of the mother, who feels satisfied and acknowledges the support received.

My mother-in-law helps me. [...] During the day, she stays with the two other children, and during the night, the father takes her home to sleep.

Mother 4.

When I left [the job], my mother bought food and her [the child's] personal items. [...] She came to see her [the child] here [hospital]. [...] My mother takes care of her [child] more than I do.

Mother 7

When the mother needs to return home to give attention to the healthy child and perform domestic activities, the extended family, represented by the aunt, contributes with care by accompanying the hospitalised child, providing affection and devotion.

I have a sister who helps a lot [...], she is a mother to my son. [...] She stopped selling her products and came here [hospital]. She stayed with him [child], I went home, cleaned the house, saw my eldest son.

Mother 2.

The support received by the family provides physical and mental strength to its members, giving them the disposition to continue their care routine at the hospital and at home. The division of tasks among family members allows the mother to focus on the care of the hospitalised child, without leaving the other children uncared for.

When I am here [hospital], she [sister] goes to my home to do the chores. [...] She washes dishes and does laundry, she takes care of his siblings. [...] However, coming here is always more difficult.
Because she is away from home, the mother contacts her bonds only by telephone. She considers it a form of emotional support and reinforcement for overcoming the adversities and limitations imposed by distance.

I live far way. The contact [...] is only by telephone. They [family members] say that everything will be okay and [...] I should be patient. [...] They give me great support from afar.

Mother 6.

\section{Friends and neighbours as sources of family support}

The relationship between the family, friends, and neighbours is an effective source of social support. Emotional support and positive social interaction can manifest as a conversation, which can provide words of encouragement and affection, strengthening hope and serving as a time for listening to vented emotions, which helps in relieving the person who is receiving this support.

They [neighbours] helped me. [...] At the time I saw him [child] pretty much dead on a bed, I didn't know what to do. [...] They [...] came to my house, [...] talked and said: "Look, a person only has what God wants. You are fighting with this child, God is watching it, you take such good care of this child [...]". This is a great help for you. [...] If someone came over when I was suffering and said a friendly word, that was everything. Because when a person has a sick child, you want to cheer up that person, not leave them feeling worse than they already are.

Mother 1.

My ex-sister-in-law, I like talking to her about my life, about what is happening. [...] When she talks to me, I feel more relieved. I don't like keeping anything to myself because it is bad to be suffering inside. I prefer to vent.

Mother 7. 
In seeking reinvigoration through faith, family members find support in the religious congregation. The bonds formed enable the provision of different types of support, such as instrumental and emotional support.

The brothers [from the church] have provided the most support in this situation. [...] They call the radio station, ask for blood donors so we will not run out of it. [...] They say that they can help with anything I need, money to buy medicine, food. [...] They also say things to me, I feel stronger, more hopeful. [...] They provide great comfort. [...] They always come here [hospital] to visit him and pray. [...] The whole church is praying for him.

Mother 5.

\section{Social support relations in healthcare services}

Since the beginning of the experience of living with the chronic illness, the support shared among mothers experiencing the same situation seems to be essential for the continuity of care for the child. This support among peers has various dimensions, such as instrumental support in its financial character, which minimises the difficulties with treatment expenses.

At the beginning, there was a person who had a son who was also receiving treatment. [...] I met her there [in another healthcare service], [...] she was very supportive, [...] mothers understand each other, they put themselves in the other's place. [...] Whenever she could, she gave me some money or gave me a ride. We spent a lot of money with the commute. [...] It was not that far, but for those who that earn the minimum wage and have expenses at home, that was a lot of money.

Mother 5
The lack of social support at home can be minimised with the support found during the child's hospitalisation. The mothers, who are ward mates, often provide emotional support and positive social interaction as they exchange knowledge and experiences. In addition, they provide a space for discussion and for venting emotions. Additionally, there is the mutual benefit of exchanging help to care for the child.

I could not find support [at home], I was crying all the time. [...] The last support I had was after starting his hospitalisation. [...] I met the mothers [ward mates] and would talk to them because I isolated myself at home. [...] The mothers told their stories, and I told mine. [...]. At home, I could not vent my emotions to anyone. [...] We felt good. They had special children like me. We gathered in there and talked [...] as if we were a family, took care of each other's children. [...] I felt relieved, with a less tight heart.

Mother 2.

We would talk. [...] We help each other during bath time. [...] I really need another person to help me, and the person who is with me in the room [ward] always helps me.

Mother 4.

The support offered by healthcare professionals has several dimensions. At times, the treatment starts in private practices in the cities located outside the state capital, where physicians who take care of the child can provide instrumental support, contributing to reducing the family expenses. Physicians contribute with this support by not accepting the consultation fee, offering free medication, and paying the costs of transportation so that the proper treatment can be conducted in the state capital. 
He used to be seen by a private doctor there [city of residence]. [...] I would arrive with no money because I didn't have a way to pay, and the doctor would not accept money for the consultation. [...] She would say: "Anything you need, you just let me know." [...] For me, my God, she was the best doctor. I would get there, and she would receive my child well and with joy.

Mother 2.

Even the doctor has helped me. [...] He gave me the inhaler [medication] two or three times.

Mother 2.

The doctor over there [city of residence] helped me a lot, referred the child [to perform the treatment in the state capital], I came in a car, and he paid the ticket.

Mother 4.

When members of the healthcare team provide guidance associated with aspects of the disease, such as symptoms, treatment, care, and implications for life, answer questions, and open spaces to discuss care, they are providing the necessary support to overcome the experience and to strengthen the supportive bond.

On the seventh day [after the birth of the child and diagnosis of the chronic disease], the [maternity ward] psychologist came and explained it to me. She was the one who came to guide me and carefully talk to me. [...] She explained it to me carefully, and I stayed quiet. [...] She was very nice. [...] I calmed down.

Mother 2

I was fifteen days without seeing anyone from the family, just crying with him. I didn't know what he had, I thought it was a disease that had no cure. Then, the doctor came to talk to me and said that there was a cure; then, I was more relieved. [...] While I was desperate, I just had bad thoughts.
The staff at the hospital in which this study was conducted have established support bonds that are strengthened during the child's hospitalisation. Emotional support is relevant and is provided by several staff members, including those responsible for cleaning the environment. The mothers recognise the importance of this support because, without affection and attention, the experience of living with the chronic condition would become even more difficult.

They treat him very well, the ones who do the cleaning here [hospital]. They give advice, support, like: "Have faith that you will get out of this, be patient." [...] She [nurse] is very helpful here [hospital] with him. [...] She said: "What do you need?" I said: What I need now is that you continue providing care to my son, to both of us. She gave me a hug. This means everything to me! I think the affection is the most important thing in these situations, other things come later, but the affection, the attention is more important.

Mother 5.

Nurses, doctors, social workers, psychologists. [...] They come to me, talk to me a lot, give me a lot of support. Thank God, at least, for that. [...] They all tell me to have faith [...] and hope that, one day, I will leave here and my son will be fine. Mother 6.

The mothers report receiving support from the healthcare team when it contributes in the routine care provided to the child, for example, when the team administer medications or provide items that the companion needs. In addition, the main carer perceives herself as receiving support when there is a good relationship with the health professionals. 
They [nursing staff] help with the medications, which they bring to my son all the time. Sometimes, they come here to know how he is doing. We go there [the nursing station] and ask for an item, they give it, ask for information, and they reply nicely, they know how to respond.

Mother 1 .

The financial assistance offered by the government to the families of chronically ill children is a type of important financial support for improving their quality of life. These resources help maintain the child and other family members on a healthy diet and also enable continuing treatment. The reason is, due to the routine care, the mother needs to reduce her working hours or leave her job, which consequently affects the family's income and can deprive the child of his or her needs.

The help from the government [sickness benefits], the money, helps her and my other daughters. I buy her personal use items, food, [...] cleaning supplies. [...] Now, it easier to maintain the house. [...] So, I don't need to work every day because I can't, I won't leave her alone. [...] I work only twice a week.

Mother 7.

\section{Discussion}

Support bonds are recognised as important determinants of health during the care process. It is understood that the support offered by the support bonds may be provided by any person who knows the reality experienced by the family and is available to provide the necessary assistance to overcome the adversities.

In the nuclear family, the support bonds consist of the healthy siblings and the father of the chronically ill child. Healthy siblings help in the care process of the sick child by participating in the treatment and in the care for the child's protection. They try to follow the guidelines given by the medical team, especially those associated with the environment, food, and household hygiene [21]. In addition, they remain at home, continuing their routine activities, and therefore, they also require care. Accordingly, the paternal contribution is significant for the mother because it reduces her concern and anxiety during a hospital stay, making her feel more peaceful and relieved because she has someone whom she can trust caring for her children.

The extended family provides instrumental support, minimising the burden on the nuclear family. In addition, it provides physical and emotional resources to maintain health and the necessary support because, without these supporters, the families would not be able to provide for all of their occasional needs and the child's needs [9]. This social support is essential for helping the family find the strength to move forward.

Regarding the healthcare professionals, initially, they must help the family understand the importance of sharing the care for a chronically ill child to have a better experience with the implications imposed by the disease $[22,23]$. When offering this type of support, healthcare professionals must empathically understand the context of the individuals involved in this process to tighten and strengthen the bonds of this relationship. In this manner, they can provide comprehensive care that is able to meet the individual needs of the chronically ill child and his or her family.

In general, the child's mother changes her routine and plans to accompany the sick child, whereas the father continues to work, keeping his job to ensure the payment of everyday and disease-related expenses $[9,11,23]$, these results corroborated with those found in the study. However, the chronic condition imposes numerous expenses that affect the family budget.

Research shows that in addition to the child's treatment costs, there is household consumption, and for some families, the financial support received from the government, such as sickness benefits and 
other social funds, is their only income [17]. Another role played by the healthcare team in supporting and helping parents during all phases of treatment is advising them about their social rights and means to access them. This support goes beyond the physical needs and reaches the psychological and social needs by providing information [24], which should be clear, logical, and timely.

The financial support provided by healthcare professionals and other institutions positively contributes to the family budget and helps in meeting the family's emergency needs. The expenses associated with the child's treatment require a considerable amount of resources, and without such support, treatment may be interrupted or discontinued, especially among low-income families [17, 25].

Spaces that promote moments for listening, discussion, and accountability are essential for coping with chronic childhood illness $[12,17]$. In this context, given that expressions of affection, esteem, and respect can occur, positive social interactions promote emotional support and simultaneously favour the exchange of life experiences, which are both able to strengthen the resilience of the carer living with the chronic condition.

This reality is feasible among families who experience a chronic childhood illness, in which, through awareness and the sharing of experiences and suffering, interest in helping and caring for others increases. This process will result in a stronger solidarity network with the development of support bonds $[10,12]$. The relationship between mothers is established because there is mutual understanding of the unique demands imposed by the chronic condition. From this perspective, the healthcare team should be aware of the importance of this relationship and thus seek strategies to further stimulate this bond.

Studies have shown the importance of religious groups in the lives of carers of chronically ill children because the support and spiritual comfort strengthen hope $[10,26]$ and also reduce stress, favou- ring the adjustment of the family and even of the child [4]. These individuals are essential for effective coping because they can also contribute financial support and meet other family demands.

Comprehensive, individualised, and diversified care should be provided, and for the presence of individuals who can provide support to the child and his or her family, it is necessary to help them meet the demands of everyday life [22]. Comprehensive healthcare is facilitated when there are links capable of providing effective and satisfactory social support.

The bonds are strengthened when families find professionals who offer informational support. These professionals can minimise anxiety and doubts by providing information about the child's condition and by answering questions that arise during routine care $[3,13,22]$. In this manner, families can make informed choices and decisions. However, the guidelines cannot be ambiguous or cause confusion [9], and the dialogue between the family and the healthcare team must be effective and affective.

In the hospital context, professionals are in daily contact with the family member who accompanies the child. Nevertheless, closer contact between the individuals involved in this context is expected to favour the relationship, the construction of bonds, and the support offered by the healthcare team.

The valorisation of the support network by the healthcare team is essential for the proposal of support and care actions that can promote maximum child development and favour the expansion of family support bonds [5].

Care at the scheduled time and the administration of medications at the prescribed time by attentive and technically competent professionals improve satisfaction with the care received [25]. However, the social support that enables coping with the difficulties imposed by the chronic condition is not restricted only to care activities.

Qualified assistance must be one of the actions developed by health professionals to make family 
members trust more in the system. Therefore, other actions must be done in health services, such as attentive listening, therapeutic dialogue, displays of affection and understanding, and sharing of knowledge. With this, there is greater likelihood of consolidation of supporting linkages, providing a better quality of life by positively helping families cope with chronic childhood illness.

The present study brings contributions to care towards children and families that have lived through chronic disease, especially to promote reflections for health professionals. That being said, the fact that this research has been done only in one scenario limits the generalization of results.

\section{Final Considerations}

By viewing support bonds as a source of positive influence on the determinants of health, their knowledge is a primary tool for effective coping and for overcoming the adversities experienced in chronic childhood illness. Such bonds provide the resources to support the practice of care in meeting the demands of families, who require care during the trajectory of the disease.

The affected child and his family need to receive care in the same way, having lived through chronic disease whether directly or indirectly. The support offered by established linkages brings great benefits to those subjects, as the measure to which a family has its needs attended to leads to better conditions to take care of the child day-to-day, making possible adequate management of chronic disease.

The necessary support to meet the demands presented by the family may be offered by nuclear and extended families; friends; neighbours; the government; healthcare professionals; and mothers who share the same experience. The support provided through these links fall under different dimensions, such as instrumental support, emotional support, informational support, reinforcement, and positive social interaction, which is present at times when the family members need care the most. Knowing the strategies adopted by family members to cope with the chronic disease in addition to their needs and the support offered by the bonds formed along the trajectory of the chronic childhood illness is essential for the establishment of comprehensive and humanised healthcare.

The weakness of the bond between the family and the Primary Healthcare team was identified, given that none of the reports indicated that these professionals are sources of support. These findings indicate that this team needs to rethink its working process because the lack of support at this level of care makes comprehensive care for the chronically ill child and his or her family more difficult. The Primary Healthcare team must assume its role as coordinator of the longitudinal and continuous care of chronically ill children to ensure their quality of life. These actions directly impact the determinants of health because the proper management of chronic illness prevents the worsening of the child's condition and unnecessary hospitalisations.

Based on the results of this study, the healthcare team should rethink its work process to provide comprehensive and humanised care to chronically ill children and their families. They should help these individuals identify ways to create support bonds within and outside the family that can contribute to providing care with autonomy and shared responsibility. In addition, healthcare professionals can build care elements that provide tools to family members that support chronically ill children to strengthen their care potential and help overcome weaknesses, positively influencing coping with the chronic condition. 


\section{References}

1. Mendes EV. O cuidado das condições crônicas na Atenção Primária à Saúde: o imperativo da consolidação da Estratégia da Saúde da Família. Brasília (DF): Organização Pan-Americana da Saúde; 2012.

2. Instituto Brasileiro de Geografia e Estatística. Pesquisa Nacional por Amostra de Domicílios: um panorama da saúde no Brasil, acesso e utilização dos serviços, condições de saúde e fatores de risco e proteção à saúde 2008. Rio de Janeiro (RJ): Fiocruz/MS/ IBGE; 2010.

3. Gondim KM, Carvalho ZMF. Sentimentos das mães de crianças com paralisia cerebral à luz da Teoria de Mishel. Esc Anna Nery. 2012 [cited on October 10, 2015]; 16(1):11-6. Available at: http://dx.doi.org/10.1590/S1414-81452012000100002

4. Drutchas A; Anandarajah G. Spirituality and coping with chronic cisease in pediatrics. R I Med J. 2014 [cited on October 12, 2015]; 97(3):26-30. Available at: http://www.ncbi.nlm.nih.gov/ pubmed/24596927

5. Dezoti AP, Alexandre AMC, Freire MHS, Mercês NNA, Mazza VA. Apoio social a famílias de crianças com paralisia cerebral. Acta Paul Enferm. 2015 [cited on October 20, 2015]; 28(2):1726. Available at: http://dx.doi.org/10.1590/1982-0194201500029

6. Christie D, Khatun H. Adjusting to life with chronic illness. Paediatric psychology. 2012 [cited on November 01, 2015]; 25(3):194-7. Available at: https://thepsychologist.bps.org.uk/ volume-25/edition-3/adjusting-life-chronic-illness

7. Amador DD, Gomes IP, Reichert APS, Collet N. Repercussões do câncer infantil para o cuidador familiar: revisão integrativa. Rev Bras Enferm. 2013 [cited on September 15, 2015]; 66(2):267-70. Available at: http://dx.doi.org/10.1590/S003471672013000200017

8. Furtado MCC, Silva LCT, Mello DF, Lima RAG, Petri MD, Rosário MM. A integralidade da assistência à criança na percepção do aluno de graduação em enfermagem. Rev Bras Enferm. 2012 [cited on September 13, 2015]; 65(1):56-64. Available at: http://dx.doi.org/10.1590/S0034-71672012000100008

9. Araújo YB, Reichert APS, Oliveira BRG, Collet N. Rede e apoio social de famílias de crianças com doença crônica: revisão integrativa. Cienc Cuid Saude. 2011 [cited on September 30, 2015]; 10(4):853-60. Available at: http://periodicos.uem.br/ojs/ index.php/CiencCuidSaude/article/view/18332

10. Nabors LA, Kichler JC, Brassell A, Thakkar S, Bartz J, Pangallo J, et al. Factors related to caregiver state anxiety and coping with a child's chronic illness. Fam Syst Health. 2013 [cited on November 01, 2015]; 31(2):171-80. Available at: http://www.ncbi.nlm.nih. gov/pubmed/23795628

11. Laakkonen H, Taskinen S, Rönnholm K, Holmberg C, Sandberg S. Parent-child and spousal relationships in families with a young child with end-stage renal disease. Pediatr. nephrol. 2014 [cited on October 10, 2015]; 29:289-95. Available at: http://www.ncbi.nlm.nih.gov/pubmed/24018797
12. Val S, Morris C, Thompson-Coon J, Ukoumunne O, Rogers M, Logan S. Peer support for parents of children with chronic disabling conditions: a systematic review of quantitative and qualitative studies. Dev Med Child Neurol. 2013 [cited on November 20, 2015]; 55(7):602-9. Available at: http://www. ncbi.nlm.nih.gov/pubmed/23421818

13. Cacante JV, Valencia MMA. Tocar los corazones em busca de apoyo: el caso de las familias de los niños com cáncera. Invest. educ. enferm. 2009 [cited on October 16, 2015]; 27(2):170-80. Available at: http://www.scielo.org.co/scielo.php?pid=S0120$53072009000200002 \&$ script=sci arttext

14. Bocchi SCM, Angelo M. Entre a liberdade e a reclusão: o apoio social como componente da qualidade de vida do binômio cuidador familiar-pessoa dependente. Rev Lat Am Enfermagem. 2008 [cited on September 15, 2015]; 16(1):15-23. Available at: http://dx.doi.org/10.1590/S0104-11692008000100003

15. Chaves ASB, Romeu G, Araujo MRM. Narrativas da experiência de pais de crianças com fibrose cística. Interface (Botucatu). 2015 [cited on November 20, 2015]; 19(55):1077-88. Available at: http://dx.doi.org/10.1590/1807-57622014.0569

16. Last JM. A dictionary of epidemiology. 6th edition. New York: Oxford University Press; 2014.

17. Nóbrega VM, Collet $N$, Silva KL, Coutinho SED. Rede e apoio social das famílias de crianças em condição crônica. Rev. eletrônica enferm. 2010 [cited on November 10, 2015]; 12(3):431-40. Available at: http://www.fen.ufg.br/revista/v12/ n3/v12n3a03.htm

18. Neves ET, Cabral IE, Silveira A. Rede familial de crianças com necessidades especiais de saúde: implicações para a enfermagem. Rev Lat Am Enfermagem. 2013 [citedon August 23, 2015]; 21(2):562-70. Available at: http://dx.doi.org/10.1590/ S0104-11692013000200013

19. Minayo MCS. O desafio do conhecimento: pesquisa qualitativa em saúde. 14ª ed. São Paulo (SP): Hucitec; 2014.

20. Minayo MCS, Assis SG, Souza ER. Avaliação por triangulação de métodos: abordagem de programas sociais. Rio de Janeiro (RJ): Fiocruz; 2014.

21. Cheron MFL, Pettengill MAM. Experiência do irmão sadio em relação à doença e hospitalização do irmão com câncer. Acta Paul Enferm. 2011 [cited on August 15, 2015]; 24(5):605-10. Available at: http://www.scielo.br/pdf/ape/v24n5/02v24n5.pdf

22. Araújo YB, Reichert APS, Vasconcelos MGL, Collet $\mathrm{N}$. Fragilidade da rede social de famílias de crianças com doença crônica. Rev Bras Enferm. 2013 [cited on October 14, 2015]; 66(5):675-81. Available at: http://dx.doi.org/10.1590/S003471672013000500006 
23. Torquato IMB, Dantas MAS, Oliveira SMD, Assis WD, Fechinne CPNS, Collet N. Participação paterna no cuidado à criança com Síndrome de Down. J Nurs UFPE on line. 2013 [cited on August 20, 2015]; 7(1):30-8. Available at: http://www.revista.ufpe.br/ revistaenfermagem/index.php/revista/article/view/3543

24. Bolla BA, Fulconi SN, Baltor MRR, Dupas G. Cuidado da criança com anomalia congênita: a experiência da família. Esc Anna Nery. 2013 [cited on November 22, 2015]; 17(2):284-90. Available at: http://dx.doi.org/10.1590/S1414-81452013000200012

25. Spir EG, Soares AVN, Wei CY, Aragaki IMM, Kurcgant P. A percepção do acompanhante sobre a humanização da assistência em uma unidade neonatal. Rev Esc Enferm USP. 2011 [cited on October 12, 2015]; 45(5):1048-54. Available at: http://dx.doi.org/10.1590/S0080-62342011000500003

26. Silva AH, Bellato R, Araújo LFS. Cotidiano da família que experiência a condição crônica por anemia falciforme. Rev. eletrônica enferm. 2013 [cited on August 23, 2015]; 15(2): 43746. Available at: http://www.fen.ufg.br/fen revista/v15/n2/pdf/ v15n2a17.pdf

Publish in International Archives of Medicine

International Archives of Medicine is an open access journal publishing articles encompassing all aspects of medical science and clinical practice. IAM is considered a megajournal with independent sections on all areas of medicine. IAM is a really international journal with authors and board members from all around the world. The journal is widely indexed and classified Q1 in category Medicine. 